\title{
PERSEPSI MAHASISWA AKUNTANSI MENGENAI PENGARUH PREVENTING, ALIENATION DAN NEUTRALIZATION TERHADAP KECENDERUNGAN BERPERILAKU CURANG
}

\begin{abstract}
A behavior person measured by the quality of education has achieved, the higher education the more good behavior. This is most words spoken of someone in general, but if we are to analyse the higher education could not guarantee a person behavior so best, the study analyzed about fraudulently behavior students accounting using indicator preventing, alienation and neutralization, there are several theories used in research is planned behavioral therapy and theory of justice. The sample accounting it uses student of Unissula second semester 2013 to 2014. A method of the data using system were delivered to students at the end of the semester. An analysis of data using statistic descriptive and the hypothesis using analysis regression SPSS assistance.The result of testing showed that the act of preventing significant to fraudulently behavior and had links negative with the significance less than $5 \%$ and unstandardized coefficients of -.403. While for variables alienation and neutralization each other significant to behavior fraudulently and had links positive for significance less than $5 \%$ and unstandardized coefficients of .986 and .355 .
\end{abstract}

Keywords: Preventing, Alienation, Neutralization and Fraudulently Behavior

\section{PENDAHULUAN}

Kualitas dari sumber daya manusia yang akan dijadikan dasar membangun bangsa sebagian besar diukur menggunakan seberapa baik prestasinya dalam dunia pendidikan yang telah mereka tempuh, Akan tetapi, kenyataannya, bukti menunjukkan bahwa prestasi yang telah mahasiswa hasilkan diperoleh dari tindakan curang secara teratur dan hanya sedikit mahasiswa yang tidak pernah curang (Kerkvliet dan Sigmund, 1999). Maka sering yang kita liat sekarang banyak dari pejabat - pejabat pemerintah, seseorang yang berpendidikan tinggi sering terkait dengan kasus hukum salah satunya adalah korupsi ini sesuai dengan berbagai penelitian akuntansi yang mengindikasikan bahwa perilaku curang yang dilakukan oleh mahasiswa akuntansi mungkin berindikasi pada perilaku profesioanal yang tidak etis di masa depan (Smith,et al.2002).

Lawson (2004) dalam penelitiannya yang berjudul "is classroom cheating related to business students' propensity to cheat in the 'real world'? " menjelaskan bahwa ada kaitan yang sangat erat antara tindakan curang di lingkungan akademik dengan tindakan tidak etis dalam dunia bisnis. Penelitian wibowo (2006) yang menggunakan responden pelajar SMU menghasilkan kesimpulan bahwa antara kecemasan akan kegagalan ujian dengan perilaku mencontek mempunyai hubungan yang positif. Dalam penelitian lain yang dilakukan oleh Atmeh dan Al Khadast (2008) mengindikasikan bahwa pencegahan, alienation dan neutralization mempunyai hubungan positif terhadap perilaku curang.

Dari beberapa penelitian tersebut bisa disimpulkan bahwa ada berbagai indicator yang sangat berpengaruh terhadap perilaku seseorang untuk berbuat curang dalam usaha memperoleh hasil studinya, 
penelitian ini akan menguji beberapa indicator yang telah dilakukan oleh peneliti sebelumnya yaitu tingkat kecemasan, alienation dan neutralization. Tujuan dari penelitian ini untuk membuktikan seberapa besar indicator - indicator diatas mampu mengukur perilaku kecurangan dari mahasiswa dalam memperoleh hasil yang maksimal dari tingkat pendidikannya. Penelitian ini akan dilakukan terhadap mahasiswa akuntansi universitas islam sultan agung yang dibedakan pada masing - masing semester yaitu semester 2 (dua), 4 (empat) dan 6 (enam).

\section{TELAAH LITERATUR DAN PENGEMBANGAN HIPOTESIS}

\section{Teori Perilaku Terencana}

Menurut teori perilaku terencana (Ajzen, 1991), yang merupakan perluasan dari teori tindakan beralasan (Ajzen dan Fishbein, 1980; Fishbein dan Ajzen, 1975), pencapaian perilaku berdasarkan pada motivasi (tujuan) dan kemampuan (pengendalian perilaku) secara bersama-sama. Motivasi berdasarkan pada pendirian terhadap perilaku, norma-norma subjektif, dan pengendalian perilaku yang dirasa. Pendirian terhadap perilaku, norma subjektif dan pengendalian perilaku yang dirasa dipengaruhi oleh berbagai variasi budaya, perseorangan, dan factor-faktor latar belakang seperti usia, jenis kelamin, pendapatan, agama, budaya, ras, kepribadian, emosi, nilai-nilai, pengalaman, perilaku di masa lalu.

\section{Teori Keadilan}

Menurut Teori Keadilan (Ikhsan dan Ishak, 2005), besarnya ketidakpuasan akan mempengaruhi motivasi. Teori keadilan secara umum merupakan bentuk dasar dari konsep hubungan pertukaran sosial. Para individu mempertimbangkan input dan output menjadi suatu nilai yang tidak seimbang. Berdasarkan teori keadilan, alienation bisa timbul karena adanya ketidakpuasan terhadap universitas, sehingga mendorong mahasiswanya untuk melakukan kecurangan akademik.

\section{Perilaku Curang}

Atmeh dan al-Khadast (2008) menyatakan bahwa menyontek dalam ujian merupakan salah satu bentuk kecurangan yang secara luas disinggung dalam studi yang berhubungan dengan kecurangan. Thornburg dalam Wibowo (2006) mengatakan bahwa mencontek merupakan pengambilan atau permintaan bantuan yang tidak legal dalam tes. Dari definisi di atas, dapat disimpulkan bahwa kecurangan (mencontek) merupakan segala tindakan ilegal ketika ujian.

Kecurangan akademik (academic fraud) dapat mengambil berbagai bentuk. Bentuk yang paling umum adalah mencoba mencontek atau menggunakan kertas contekkan dalam ujian. Beberapa tindakan yang dikategorikan kecurangan akademik adalah menggunakan bantuan dalam ujian yang tidak diijinkan secara terbuka, mencoba membaca apa yang ditulis oleh kandidat lain selama ujian, bertukar informasi didalam tempat ujian, menggunakan identitas orang lain selama ujian, dan lainnya. 


\section{Preventing}

Berdasarkan teori perilaku terencana, determinan ketiga dari intention adalah tingkatan atas kontrol perilaku yang dihayati (the degree of perceived behavioral control) yang merujuk pada kemudahan atau kesulitan untuk menampilkan perilaku tertentu serta asumsi yang dibuat oleh individu yang mencerminkan pengalaman masa lalu sebagai bahan antisipasi dalam menghadapi rintangan (Rokhmah, 2005). Kontrol perilaku yang dihayati merupakan persepsi seseorang tentang bisa tidaknya melakukan atau mencapai suatu tujuan atau motivasi (intention). Dari uraian diatas dapat disimpulkan bahwa diantara berbagai keyakinan yang akhirnya akan menentukan intention dan perilaku tertentu adalah keyakinan mengenai tersedia atau tidaknya kesempatan dan sumber yang dimiliki (Rokhmah, 2005). Keyakinan ini dapat berasal dari pengalaman perilaku curang di masa lalu, dapat juga informasi dari teman yang pernah melakukannya, dan dapat juga oleh faktor lain yang mengurangi atau menambah kesan kesukaran untuk melakukan perilaku curang. Jadi pencegahan, berkaitan dengan kontrol perilaku yang dihayati, yang pada akhirnya mempengaruhi intention dan perilaku seseorang. Berdasarkan teori perilaku terencana, maka dapat diambil hipotesis yang pertama yaitu:

$\mathrm{H} 1$. Preventing mempunyai hubungan negatif dengan perilaku curang diantara mahasiswa akuntansi.

\section{Alienation}

Determinan pertama intention yaitu sikap terhadap perilaku, merujuk pada tingkatan yang dimiliki oleh individu dalam membuat evaluasi yang sifatnya favorabel atau unfavorabel terhadap suatu perilaku (Rokhmah, 2005). Sikap itu sendiri merupakan suatu hal yang mempelajari mengenai seluruh tendensi tindakan, baik yang menguntungkan maupun yang kurang menguntungkan, tujuan manusia, objek, gagasan atau situasi (Ikhsan dan Ishak, 2005). Sikap cenderung bersifat membimbing perilaku, dan orang-orang memperoleh sikap dari pengalaman pribadi, orang tua, panutan dan kelompok (Ikhsan dan Ishak, 2005).

Pengalaman pribadi seorang mahasiswa yang merasa mendapat perlakuan tidak adil dari universitas, bisa menimbulkan sikap alienation. Alienation merupakan perasaan seseorang yang merasa diasingkan di lingkungan universitasnya. Sikap alienation seorang mahasiswa ini akan mendorong timbulnya perilaku curang, karena kalau universitasnya saja tidak etis maka bagaimana mahasiswanya mau berperilaku etis. Berdasarkan teori diatas, maka hipotesis yang kedua yaitu:

H2. Alienation mempunyai hubungan positif dengan perilaku curang diantara mahasiswa akuntansi.

\section{Neutralization}

Determinan pertama dari intention yaitu sikap terhadap perilaku. Sikap adalah suatu hal yang mempelajari mengenai seluruh tendensitindakan, baikyang menguntungkan maupun yang kurang menguntungkan, tujuan manusia, objek, gagasan atau situasi (Ikhsan \& Ishak, 2005). Sikap merupakan wahana dalam membimbing perilaku. Orang-orang memperoleh sikap dari pengalaman pribadi, orang tua, panutan dan kelompok.

Neutralization merupakan hal-hal yang mendorong perilaku curang, dimana dia lebih ke permasalahan 
pribadi masing-masing individu, seperti mahasiswa yang terancam kehilangan beasiswa apabila nilai ujiannya rendah. Sikap neutralization ini bisa timbul karena pengalaman diri sendiri yang pernah kehilangan beasiswa, sehingga untuk menghindarinya terulang kembali, mahasiswa tersebut terdorong untuk melakukan kecurangan ketika ujian, maka hipotesis yang ketiga yaitu:

H3. Neutralization mempunyai hubungan positif dengan perilaku curang diantara mahasiswa akuntansi

\section{METODE PENELITIAN}

Populasi dalam penelitian ini adalah seluruh mahasiswa program sarjana yang mengikuti kuliah akuntansi semester genap pada tahun akademik 2013-2014. sampel akan dipilih secara acak dan kuesioner dibagikan pada akhir semester. Studi ini untuk menyediakan informasi mengenai perbedaan individual tentang perilaku curang dan untuk menguji jika ada hubungan yang signifikan antara preventing (pencegahan), alienation (pengasingan) dan netralisasi di satu sisi dan persepsi mahasiswa tentang tindak kecurangan di sisi lain. Sedangkan alat analisis statistik yang digunakan :

Analisis deskriptif untuk menghitung rata-rata dan standar deviasi untuk variable-variabel dan bagianbagian yang berbeda di kuesioner.

Analisis regresi untuk menentukan apakah ada hubungan yang signifikan antara variable independent yang dipilih dan persepsi mahasiswa tentang tindakan kecurangan.

Analisis deskriptif dan regresi digunakan oleh banyak studi sebelumnya. Beberapa studi sebelumnya menghasilkan analisis yang signifiknan sedangkan yang lainnya tidak. Model regresi yang digunakan dalam studi ini untuk menguji perkiraan perilaku kecurangan ditunjukkan sebagai berikut :

$$
\begin{aligned}
& \text { Kecurangan }=a 0+a 1 \text { pencegahan }+ \text { ei } \\
& \text { Kecurangan }=a 0+a 1 \text { pengasingan }+ \text { ei } \\
& \text { Kecurangan }=a 0+a 1 \text { netralisasi }+ \text { ei }
\end{aligned}
$$

Dimana a0, a1, a2, a3 merupakan koefisien dari model regresi.

White-test untuk hasil untuk hasil heteroskedasticity menghasilkan ukuran sebesar chi-square sebesar 8,54, yang tidak signifikan bahkan pada tingkat 0,05.

\section{HASIL DAN PEMBAHASAN}

\section{Analisis Deskriptif}

Statistik deskriptif digunakan untuk memberikan gambaran mengenai variabel-variabel penelitian yang terdiri dari : preventing, alienation, neutralization, kecurangan sebelumnya dan kemungkinan kecurangan.

Dari tabel 1 bisa disimpulkan bahwa nilai mean untuk pencegahan sebesar 3.69, menunjukkan bahwa pencegahan cukup ketat penerapannya. Standar deviasi untuk pencegahan lebih kecil dari 1.107 maka ada variasi yang lebih kecil dari variasi tersebut. Nilai minimum untuk pencegahan adalah 1 artinya sangat tidak setuju dengan pernyataan kuesioner tentang variabe pencegahan, dan nilai maximum untuk pencegahan adalah 5 artinya sangat setuju.

Nilai mean untuk alienation sebesar 3.13 menunjukkan bahwa akademis yang bersangkutan harus lebih 
fair, pengorganisasian komunitas yang lebih baik. Standar deviasi untuk alienation lebih besar dari 0.939 maka ada variasi yang lebih besar dari variasi tersebut. Nilai minimum untuk alienation adalah 1 artinya sangat tidak setuju dengan pernyataan kuesioner tentang variabel alienation, dan nilai maximum untuk alienation adalah 5 artinya sangat setuju.

Nilai mean untuk neutralization sebesar 2.94. Standar deviasi untuk neutralization lebih besar dari 0.882 maka ada variasi yang lebih besar dari variasi tersebut. Nilai minimum untuk neutralization adalah 1 artinya sangat tidak setuju dengan pernyataan kuesioner tentang variabel neutralization dan nilai maximum untuk neutralization adalah 5 artinya sangat setuju

Nilai mean untuk kecurangan sebelumnya sebesar 2.75. Standar deviasi untuk kecurangan sebelumnya lebih besar dari 0.825 maka ada variasi yang lebih besar dari variasi tersebut. Nilai minimum untuk kecurangan sebelumnya adalah 1 artinya sangat tidak setuju dengan pernyataan kuesioner tentang variabel kecurangan sebelumnya dan nilai maximum untuk kecurangan sebelumnya adalah 5 artinya sangat setuju.

Nilai mean untuk kemungkinan kecurangan sebesar 3.18. Standar deviasi untuk kemungkinan kecurangan lebih besar dari 0.954 maka ada variasi yang lebih besar dari variasi tersebut. Nilai minimum untuk kemungkinan kecurangan adalah 1 artinya sangat tidak setuju dengan pernyataan kuesioner tentang variabel kemungkinan kecurangan dan nilai maximum untuk kemungkinan kecurangan adalah 5 artinya sangat setuju.

\section{Uji Validitas}

Pada tabel 2 bisa dilihat bahwa besarnya $r$ hitung untuk variabel pencegahan lebih besar dari $r$ tabel, maka dapat disimpulkan bahwa semua indikator untuk mengukur variabel pencegahan adalah valid. Besarnya $r$ hitung untuk variabel alienation semuanya lebih besar dari $r$ tabel, kecuali untuk alienation 6, maka khusus untuk alienation 6 tidak dimasukkan ke dalam uji asumsi klasik dan analisis regresi. Besarnya $r$ hitung untuk variabel neutralization lebih besar dari $r$ tabel, maka dapat disimpulkan bahwa semua indikator untuk mengukur variabel neutralization adalah valid. Besarnya $r$ hitung untuk variabel kecurangan sebelumnya lebih besar dari $r$ tabel, maka dapat disimpulkan bahwa semua indikator untuk mengukur variabel kecurangan sebelumnya adalah valid. Besarnya $r$ hitung untuk variabel kemungkinan kecurangan lebih besar dari $r$ tabel, maka dapat disimpulkan bahwa semua indikator untuk mengukur variabel kemungkinan kecurangan adalah valid.

\section{Uji Reliabilitas}

Pada tabel 3 menunjukkan bahwa Cronbach's Alpha untuk variabel pencegahan sebesar .911, alienation sebesar .745, neutralization sebesar .866, kecurangan sebelumnya sebesar .882 dan kemungkinan kecurangan sebesar .825. Nilai Cronbach's Alpha untuk semua variabel penelitian ini lebih besar dari 0,60 (Nunnaly, 1967), maka dapat disimpulkan bahwa semua variabel yang diuji dapat dikatakan reliabel.

\section{Regresi untuk Preventing dengan Perilaku Curang}

Dari analisis regresi pada tabel 4, pencegahan berpengaruh secara signifikan terhadap kecurangan dan 
mempunyai hubungan yang negatif. Hal itu dapat dilihat dari tingkat signifikansi pencegahan yang lebih kecil dari 5\% dan unstandardized coefficients sebesar -.403. Nilai adjusted R2 diperoleh sebesar 0.096 yang berarti bahwa $9.6 \%$ kecurangan dapat dijelaskan variabel pencegahan sedangkan sisanya 100\% - 9.6\% $=90.4 \%$ kecurangan dijelaskan oleh variabel lainnya. Koefisien regresi pencegahan sebesar - 0.403 menyatakan bahwa setiap pencegahan meningkat 1000x maka tingkat kecurangan akan turun sebesar 403 . Koefisien regresi pencegahan bernilai - (negatif) artinya pencegahan mempunyai hubungan yang negatif dengan perilaku curang.

\section{Regresi untuk alienation dengan Perilaku Curang}

Dari analisis regresi pada tabel 5, alienation berpengaruh secara signifikan terhadap kecurangan dan mempunyai hubungan yang positif. Hal itu dapat dilihat dari tingkat signifikansi alienation yang lebih kecil dari 5\% dan unstandardized coefficients sebesar .986. Nilai adjusted R2 diperoleh sebesar 0.201 yang berarti bahwa 20.1 \% kecurangan dapat dijelaskan variabel alienation sedangkan sisanya 100\% - 20.1\%= $79.9 \%$ kecurangan dijelaskan oleh variabel lainnya. Koefisien regresi alienation sebesar 0.986 menyatakan bahwa setiap alienation meningkat 1000x maka tingkat kecurangan akan naik sebesar 986 . Koefisien regresi alienation bernilai + (positif) artinya alienation mempunyai hubungan yang positif dengan perilaku curang.

\section{Regresi untuk neutralization dengan Perilaku Curang}

Dari analisis regresi pada tabel 6, neutralization berpengaruh secara signifikan terhadap kecurangan dan mempunyai hubungan yang positif. Hal itu dapat dilihat dari tingkat signifikansi neutralization yang lebih kecil dari 5\% unstandardized coefficients sebesar .355. Nilai adjusted R2 diperoleh sebesar 0.057 yang berarti bahwa 5.7\% kecurangan dapat dijelaskan variabel neutralization sedangkan sisanya 100\% - 5.7\% = 94.3\% kecurangan dijelaskan oleh variabel lainnya. Koefisien regresi neutralization sebesar 0.355 menyatakan bahwa setiap neutralization meningkat 1000x maka tingkat kecurangan akan naik sebesar 355 . Koefisien regresi neutralization bernilai + (positif) artinya neutralization mempunyai hubungan yang positif dengan perilaku curang.

\section{PEMBAHASAN}

\section{Preventing terhadap Perilaku Curang}

Berdasarkan hasil analisis regresi dalam penelitian ini, telah ditunjukkan bahwa pencegahan berpengaruh secara signifikan terhadap perilaku curang dan mempunyai hubungan negatif. Hal ini berarti bahwa hipotesis 1 dalam penelitian ini diterima. Apabila akademis semakin meningkatkan penjagaan yang ketat selama ujian, maka kemungkinan mahasiswa melakukan kecurangan semakin kecil. Penjagaan yang ketat ketika ujian mempengaruhi persepsi mahasiswa akan mudah dan sukarnya melakukan kecurangan, dan hal itu akan mempengaruhi muncul dan tidaknya perilaku curang tersebut. Hasil penelitian ini sesuai dengan teori perilaku terencana yang menyatakan bahwa kontol perilaku dihayati ikut mempengaruhi munculnya perilaku seseorang. 


\section{Alienation terhadap Perilaku Curang}

Berdasarkan hasil analisis regresi dalam penelitian ini, telah ditunjukkan bahwa alienation berpengaruh secara signifikan terhadap perilaku curang dan mempunyai hubungan positif. Hal ini berarti bahwa hipotesis 2 dalam penelitian ini diterima. Apabila seorang mahasiswa semakin merasa diasingkan atau mendapat perlakuan yang tidak adil, maka kemungkinan dia untuk melakukan kecurangan pun juga semakin besar. Hasil penelitian ini sesuai dengan teori perilaku terencana yang menyatakan bahwa sikap terhadap perilaku mempengaruhi intention, yang pada akhirnya akan munculnya perilaku curang tersebut. Hasil penelitian ini juga sesuai dengan teori keadilan, yang menyatakan bahwa besarnya ketidakpuasan akan mempengaruhi motivasi, dan motivasi ini juga akan mempengaruhi munculnya perilaku curang tersebut. Hasil analisis regresi dalam penelitian ini juga sesuai dengan penelitian yang dilakukan oleh Atmeh dan Al-Khadast (2008).

\section{Neutralization terhadap Perilaku Curang}

Berdasarkan hasil analisis regresi dalam penelitian ini, telah ditunjukkan bahwa neutralization berpengaruh secara signifikan terhadap perilaku curang dan mempunyai hubungan positif. Hal ini berarti bahwa hipotesis 7 dalam penelitian ini diterima. Hasil penelitian ini sesuai dengan teori perilaku terencana menyatakan bahwa sikap terhadap perilaku mempengaruhi intention, yang pada akhirnya akan munculnya perilaku curang tersebut. Hasil analisis regresi dalam penelitian ini juga sesuai dengan penelitian yang dilakukan oleh Atmeh dan Al-Khadast (2008).

\section{SIMPULAN}

Setelah penulis melakukan pengujian terhadap variabel - variabel yang ada yaitu preventing, alinetation, dan neutralisation terhadap perilaku curang terhadap mahasiswa akuntansi unissula penulis memperoleh beberapa kesimpulan inti yaitu : Hipotesis pertama dalam penelitian ini diterima, mengingat semakin preventing (pencegahan) ditingkatkan maka tingkat perilaku curang akan semakin turun. Hipotesis kedua dalam penelitian ini diterima. Seorang mahasiswa yang merasa diasingkan, mempunyai motivasi yang lebih tinggi untuk melakukan kecurangan dibandingkan mahasiswa lainnya. Hipotesis ketiga dalam penelitian ini juga diterima. Seorang mahasiswa yang mempunyai permasalahan pribadi, seperti : dia terancam kehilangan beasiswa jika nilai ujiannya rendah, mempunyai motivasi yang lebih tinggi untuk melakukan kecurangan dibandingkan mahasiswa lainnya.

\section{Keterbatasan Penelitian}

Sampel mahasiswa yang digunakan hanya mahasiswa Unissula, sehingga hanya diperoleh sampel penelitian yang relatif kecil jumlahnya dan tidak bisa mewakili keseluruhan mahasiswa akuntansi di perguruan tinggi semarang khususnya. Varibel yang digunakan hanya 3 (tiga) saja yaitu Preventing, Alienation dan Neutralisation.

\section{Saran}

Saran ini ditujukan untuk memberikan masukan positif bagi peneliti selanjutnya yang ingin 
mengembangkan penelitian sejenis :

sampel yang digunakan sebaiknya lebih kompleks baik dari segi jumlah mahasiswa yang dijadikan responden maupun perguruan tingginya.

varibel yang digunakan kedepan sebaiknya lebih banyak lagi agar bisa menghasilkan temuan baru untuk mengatasi perilaku curang di lingkungan mahasiswa umumnya dan kampus khususnya.

bagi kalangan akademis diharapkan bisa menjadi masukan untuk memperbaiki perilaku mahasiswa guna meningkatkan mutu lulusan kedepan agar lebih berkualitas.

\section{DAFTAR PUSTAKA}

Atkinson, Hilgard, (1999), Introduction to Pshcology, Eight edition, Harcourt Brace Jova Novich Publishers Atmeh M. , Al Khadast H. , (2008), "Factors Affecting Cheating Behaviour among accounting Students" Journal of Accounting-Business \& Management. 109-125

Bernardi A.R. , Metzger L.R., Scofield B.G.R., Wade H.A.M., (2004), “Examining the Decision Process of Students' Cheating Behavior: An Empirical Study", Journal of Business Ethics. Vol. 50, Iss. 4, pg. 397

Dayakisni T. , Salis Y. (2004), Psikologi Lintas Budaya, Malang : UMM Press

Ghozali, I. (2006), Aplikasi Analisis Multivariate dengan Program SPSS, Badan Penerbit Universitas Diponegoro, Semarang

Halida R. , Litbang Media Group, " Mayoritas Siswa-Mahasiswa Menyontek”, Media Indonesia 23 April 2007

Ikhsan A. , Ishak M. , (2005), Akuntansi Keperilakuan, Jakarta : Salemba Empat

Irwanto, Elia H. , Hadisoepadma A. , Priyani R. , Wismanto B.Y. , Fernandes C. , (1997), Psikologi Umum : Buku Panduan Mahasiswa, Jakarta : PT Gramedia Pustaka Utama

Ivancevich M.J. , Robert K. , Michael T.M. , (2007), Perilaku dan Manajemen Organisasi, Jakarta; Erlangga

Lawson A.R. ; (2004), Is Classroom Cheating Related to Business Students' Propensity to Cheat in the "Real World"? , Journal of Business Ethics. Vol. 49, Iss. 2, pg. 189

Novriani L.H. , (2008), Pengaruh Kecerdasan Intelektual, Kecerdasan Emosional, Kecerdasan Spiritual dan Gender terhadap Sikap Etis Mahasiswa Akuntansi, Skripsi, Undip

Oxford English Dictionary. 1992. New Edition. Oxford : Oxford University Press.

Rokhmah E.B. , (2005), Keterkaitan antara Komitmen Afektif dengan Intensi Turnover pada Karyawan Bagian

Produksi di PT. Usman Jaya Mekar Magelang, Skripsi, Universitas Sebelas Maret Surakarta, diakses 29 November 2008

Santoso S. , (2004), Buku Latihan SPSS Statistik Parametrik, Jakarta : PT Elex Media Komputindo Kelompok Gramedia.

Sekaran U. , (2006), Research Methods For Business, Jakarta : Salemba Empat

Siegel G. , Ramanauskas H. , Marconi, (1989), Behavioral Accounting, Ohio : South Western Publishing Co

Sujana Y.E \& R. Wulan, (!994), Hubungan Antara Kecenderungan Pusat Kendali dengan Intensi Menyontek, Jurnal Psikologi, NO 2, 1-8 
Supratiknya, (1995), Mengenal Perilaku Abnormal, Yogyakarta : Kanisius

Whitley Jr. Bernard E., Amanda B.N., Curtis J.J., (1999), Gender Differences in Cheating Attitudes and Classroom Cheating Behavior : A Meta Analysis, Sex Roles, Nov 1999, 41, 9/10, Academic Research Library, pg. 657.

Wibowo Y. A. , (2006), Perilaku Mencontek Ditinjau dari Kecemasan akan Kegagalan Ujian pada Pelajar SMU, Skripsi, Unika Soegijapranata.

Jurnal Akuntansi Indonesia 


\section{LAMPIRAN}

Tabel 1

Statistik Deskriptif

\begin{tabular}{lllll}
\hline Nama Variabel & Minimum & Maximum & Mean & Standar Deviasi \\
\hline & 1 & 5 & 3.69 & 1.101 \\
Pencegahan & 1 & 5 & 3.13 & 1.053 \\
Alienation & 1 & 5 & 2.94 & 1.028 \\
Neutralization & 1 & 5 & 2.75 & 1.040 \\
Kecurangan Sebelumnya & 1 & 5 & 3.18 & 1.029 \\
Kemungkinan Kecurangan & & & & \\
\hline
\end{tabular}

Tabel 2

Uji Reliabilitas

\begin{tabular}{lll}
\hline Nama Variabel & Cronbach's Alpha & Kesimpulan \\
\hline Preventing & .911 & Reliabel \\
\hline Alienation & .745 & Reliabel \\
\hline Neutralization & .866 & Reliabel \\
\hline Kecurangan Sebelumnya & .882 & Reliabel \\
\hline Kemungkinan Kecurangan & .825 & Reliabel \\
\hline
\end{tabular}

Tabel 3

Regresi Preventing terhadap Perilaku Curang

Model Summary

\begin{tabular}{|l|l|r|r|r|}
\hline Model & R & R Square & $\begin{array}{c}\text { Adjusted } \\
\text { R Square }\end{array}$ & $\begin{array}{r}\text { Std. Error of } \\
\text { the Estimate }\end{array}$ \\
\hline 1 & $.321 \mathrm{a}$ & .103 & .096 & 10.352 \\
\hline
\end{tabular}

a. Predictors: (Constant), Pencegahan

Coefficientsa

\begin{tabular}{|ll|r|r|r|r|r|}
\hline \multirow{2}{*}{ Model } & \multicolumn{2}{|c|}{$\begin{array}{c}\text { Unstandardized } \\
\text { Coefficients }\end{array}$} & $\begin{array}{c}\text { Standardized } \\
\text { Coefficients }\end{array}$ & & \\
\cline { 3 - 5 } & \multicolumn{1}{|c|}{$\mathrm{B}$} & Std. Error & Beta & \multicolumn{1}{c|}{$\mathrm{t}$} & \multicolumn{1}{c|}{ Sig. } \\
\hline 1 & (Constant) & 76.155 & 4.469 & & 17.043 & .000 \\
& Pencegahan & -.403 & .108 & -.321 & -3.746 & .000 \\
\hline
\end{tabular}

a. Dependent Variable: Kecurangan 


\section{Tabel 4}

\begin{tabular}{llcccc}
\multicolumn{5}{c}{ Regresi Alineation terhadap Perilaku Curang } \\
\hline \multicolumn{4}{c}{ Model Summary } \\
\hline Model & $\mathrm{R}$ & R Square & $\begin{array}{c}\text { Adjusted R } \\
\text { Square }\end{array}$ & $\begin{array}{c}\text { Std. Error of the } \\
\text { Estimate }\end{array}$ \\
\hline 1 & $.455^{\mathrm{a}}$ & .207 & \multicolumn{2}{c}{.201} & 9.732 \\
\hline a. Predictors: (Constant), alienation & & \\
\hline
\end{tabular}

\begin{tabular}{|c|c|c|c|c|c|c|}
\hline \multicolumn{7}{|c|}{ Coefficients $^{a}$} \\
\hline \multirow{3}{*}{ Model } & & \multirow{2}{*}{\multicolumn{2}{|c|}{ Unstandardized Coefficients }} & Standardized & \multirow{3}{*}{$\mathrm{T}$} & \multirow{3}{*}{ Sig. } \\
\hline & & & & Coefficients & & \\
\hline & & B & Std. Error & Beta & & \\
\hline \multirow{2}{*}{1} & (Constant) & 38.433 & 3.878 & & 9.912 & .000 \\
\hline & alienation & .986 & .174 & .455 & 5.651 & .000 \\
\hline
\end{tabular}

Tabel 6

Regresi Neutralization terhadap Perilaku Curang

\begin{tabular}{|l|r|r|r|r|}
\multicolumn{7}{c|}{ Model Summary } \\
\hline Model & R & R Square & $\begin{array}{c}\text { Adjusted } \\
\text { R Square }\end{array}$ & $\begin{array}{c}\text { Std. Error of } \\
\text { the Estimate }\end{array}$ \\
\hline 1 & $.253 a$ & .064 & .057 & 10.575 \\
\hline
\end{tabular}

a. Predictors: (Constant), Neutralization

\section{Coefficientsa}

\begin{tabular}{|c|c|c|c|c|c|c|}
\hline \multirow[b]{2}{*}{ Model } & & \multicolumn{2}{|c|}{$\begin{array}{l}\text { Unstandardized } \\
\text { Coefficients }\end{array}$} & \multirow{2}{*}{$\begin{array}{c}\begin{array}{c}\text { Standardized } \\
\text { Coefficients }\end{array} \\
\text { Beta }\end{array}$} & \multirow[b]{2}{*}{$\mathrm{t}$} & \multirow[b]{2}{*}{ Sig. } \\
\hline & & $\mathrm{B}$ & Std. Error & & & \\
\hline 1 & (Constant) & 47.280 & 4.425 & & 10.684 & .000 \\
\hline & Neutralization & .355 & .123 & .253 & 2.893 & .005 \\
\hline
\end{tabular}

a. Dependent Variable: Kecurangan

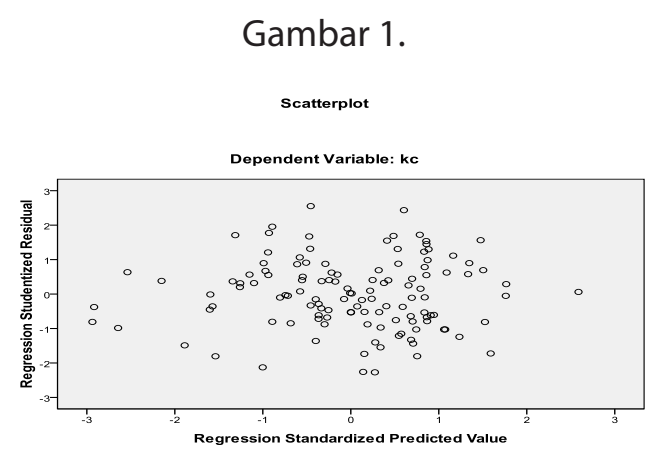




\section{Gambar 2}

Uji Normalitas

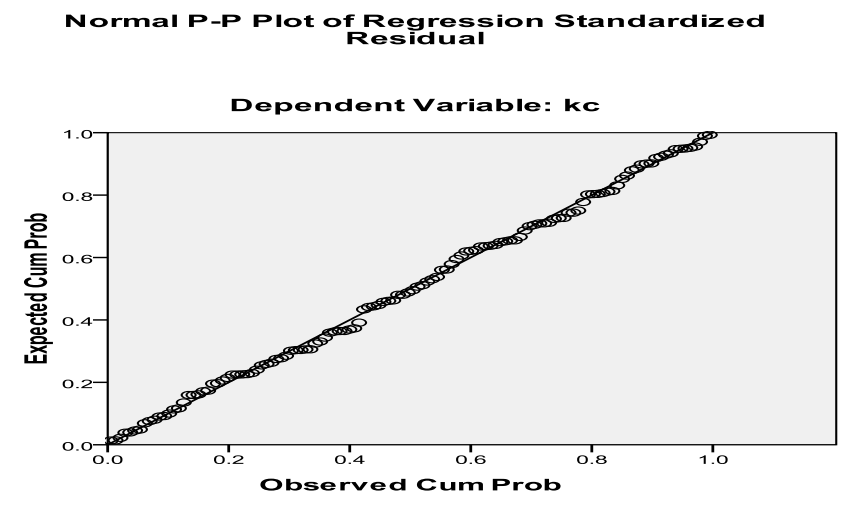

